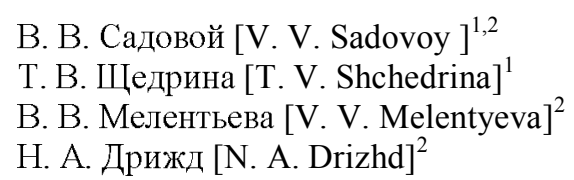

УДК 36-9

\title{
РАЗРАБОТКА ТЕХНОЛОГИИ ПИЩЕВОЙ ДОБАВКИ С ПРОФИЛАКТИЧЕСКИМИ СВОЙСТВАМИ
}

\section{THE DEVELOPMENT OF TECHNOLOGY OF FOOD ADDITIVES WITH PREVENTIVE PROPERTIES}

\author{
${ }^{1}$ Северо-Кавказский федеральный университет (филиал) в г. Пятигорске/ \\ North- Caucasus Federal University (branch) in Pyatigorsk, \\ ${ }^{2}$ Ставропольский институт кооперации (филиал) БУКЭП / \\ Stavropol Institute of Cooperation (branch) BUKEP
}

\begin{abstract}
Анномация. Исследованы квантово-химические характеристики молекул флавоноидов выљимок красного винограда. Установлены оптимальные режимы экстракиии сопутствуоиих ингредиентов из виноградиьх выжсимок (mит-руемье кислоты, сахара и другие органические соединения). Осадок отделяли от раствора, измельчали и суиили. $B$ резуль-тате получали пицевую профилактическую добавку с антиоксидантньми свойствами.
\end{abstract}

Ключевые слова: флавоноиды, виноградные выжимки, молекулярные свойства, экстракция, оптимизация, антиоксиданты, пищевая антиоксидантная добавка.

Abstract. The investigated quantum-chemical characteristics of the molecules of flavonoids of pomace from red grapes. The optimal modes of extraction of the accompanying ingredients from grape pomace (titrable acids, sugars and other organic compounds) are established. The sediment was separated from the solution, crushed and dried. As a result, we received a food preventive additive with antioxidant properties.

Key words: flavonoids, grape pomace, molecular properties, extraction, optimization, antioxidants, food antioxidant additive.

Introduction. In the Russian Federation, the average annual grape processing is 250 thousand tons. In the Stavropol Territory, 18 primary winemaking enterprises are engaged in the cultivation and processing of grapes, the production capacity of these organizations is 120 - 130 thousand tons of grapes per year. However, grape pomace is used to feed livestock or transported to the fields as organic fertilizer. The main reason for the irrational use of secondary raw materials for grape processing is the lack of effective technology $[1 ; 2]$.

In modern theories about nutrition, much attention is paid to biologically active components of food, which determine the therapeutic and therapeutic-prophylactic effect. Special interest is paid to the development of a technology for processing grape pomace of red grapes, which contains a significant amount of biological antioxidants that reduce the activity of oxidative processes of radicals. Unsaturated fatty acids, which are part of phospholipids, are mainly subjected to oxidation in biological membranes. At the stage of initiation (in the alpha position), a proton ( $\mathrm{H} \bullet$ ) is abstracted along the double bond between the carbon atoms. The $\mathrm{CH}$ bond is also weakened in adjacent carbon atoms, facilitating the elimination of a proton. The radical with carbon undergoes rearrangement and combines with oxygen to form a peroxide radical capable of separating a hydrogen atom from another unsaturated fatty acid $[5,6]$.

Phenolic compounds (with an aromatic ring) are the largest group among natural and synthetic antioxidants. As a result, a negative charge is shifted to the hydroxyl group, which contributes to the abstraction of a proton from the $\mathrm{OH}$ group and the formation of phenoxy radical isomers. Consequently, antioxidants flavonoids reduce the formation of peroxide radicals $[1,2]$.

Materials and methods. As a result of numerous studies, it has been found that red grapes, consumed regularly in the diet, have a beneficial effect on the human heart and circulatory system. It turns out that the polyphenolic compounds (flavonoids) contained in its composition significantly reduce the likelihood of blood clots. Dry red wine and red grapes (wine itself and grape pomace) contain powerful antioxidants - quercetin, resveratrol, epicatechin, catechin, epicatechin gallate, rutin and others $[7,8]$.

The purpose of this research was to develop a technology for obtaining an antioxidant food supplement enriched with flavonoids from grape pomace.

The object of research was grape pomace obtained from the red grape variety "Levokumsky resilient" grown in Zarya CJSC of the Levokumsky region of the Stavropol Territory. Extraction of sugars, tartaric acids and protein from grape pomace was carried out on a laboratory extractor of the ES-8110 brand. Temperature control during extraction was carried out in a 1TG-0-03 water thermostat. During the experimental studies, ingredients and materials approved for use by the state sanitary epidemiological supervision were used. 
The $\mathrm{pH}$ value was determined in aqueous extracts by potentiometric method on a $\mathrm{pH}$-meter-340. The protein content (in mass fractions) was determined by the Kjeldahl method; ash - by burning in a muffle furnace, followed by calcining a sample of the mineral residue; mass fraction of moisture - on a moisture analyzer brand OHAUS MB 45. Determination of the quantitative content of sugars was carried out by photocolorimetry, the interaction in an alkaline medium of carbonyl groups of sugars with iron cyanide potassium [4]. The mass concentration of titratable acids of the test solution was determined by titration with sodium hydroxide (concentration $0.1 \mathrm{~mol} / \mathrm{dm} 3$ ) in the presence of phenolphthalein [3].

The data obtained was analyzed in Statistic v. 10 and the StatisticNeuralNetworks module. The experiments were carried out in 3-5 repetitions. Prediction of the molecular properties of chemical compounds was carried out in HyperChem v. 8.

When in contact with air, grape pomace quickly oxidizes and becomes moldy, acetic acid is formed instead of alcohol, and tartaric acid compounds are destroyed by propionic fermentation bacteria. Therefore, it is advisable to process the pomace immediately after pressing by extracting sugars, tartaric acids and other compounds.

The diffusion phenomenon underlies the extraction of tartaric acids and sugars from grape pomace. The diffusion process consists in the penetration of solutions of different concentrations of the solute into each other. Based on this, at the initial stage of the research, the molecular characteristics of the flavonoids quercetin, resveratrol, rutin, epicatechin, catechin, and epicatechin gallate were studied using computer simulation methods.

Results and discussion. When studying the distribution of the charge density on the surface of molecules and structures of flavonoids, it was revealed that almost all the compounds under study have hydrophobic properties (the deviation of the values of the charge values from zero is small), although there are insignificant hydrophilic zones. In fig. 1 shows the surface of the charge density distribution and the structural formula of the catechin molecule.

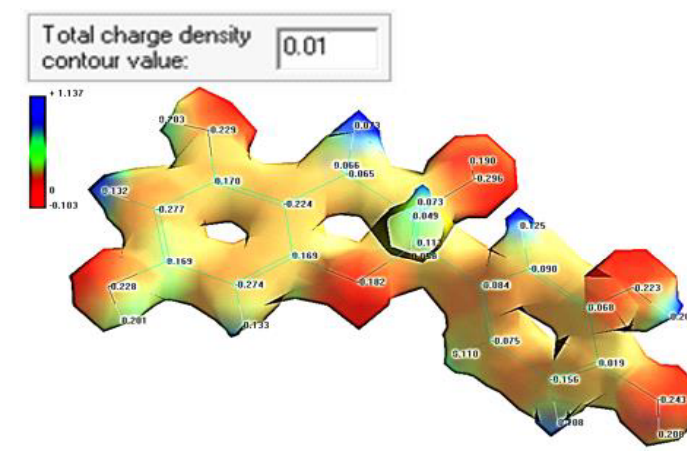

a)

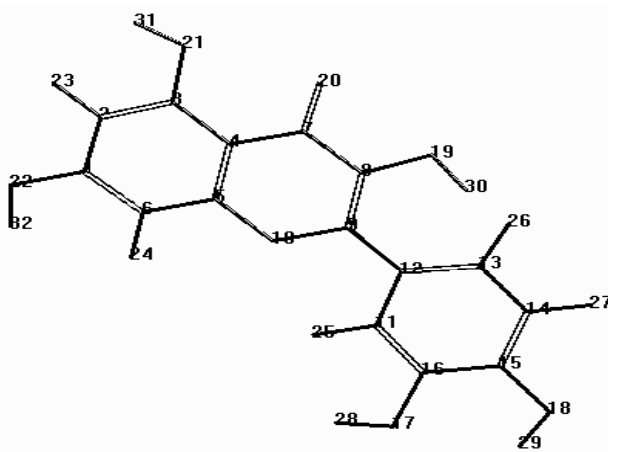

b)

Fig. 1. Catechin molecule: a - charge density distribution surface; $b$ - structural formula

The proof of the hydrophobicity of flavonoids can be the value of the total charge density, presented in table. 1 .

The data obtained indicate that it is advisable to use non-polar organic solvents for the extraction of flavonoids; at the same time, it is known that polar solutions are usually used for the extraction of sugars (alcohol) and tartaric acid compounds.

The temperature, the value of active acidity $(\mathrm{pH})$, the duration of the process, and the ionic strength of the solution have a significant effect on the conditions for the diffusional distribution of substances between liquid phases. ( $t$, $\left.\mathrm{pH}, \tau, \mathrm{C}_{\mathrm{NaCI}}\right)$.

Table 1

The final charge density of the investigated flavonoid molecules

\begin{tabular}{|c|c|c|c|c|c|c|}
\hline \multirow[b]{2}{*}{ Specifications } & \multicolumn{6}{|c|}{ Flavonoids } \\
\hline & 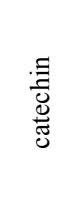 & 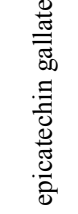 & 䍖 & 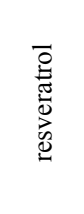 & 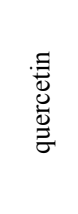 & 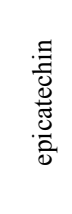 \\
\hline Final charge density, eV & 0,010 & 0,010 & 0,095 & 0,050 & 0,010 & 0,010 \\
\hline
\end{tabular}

The study of extraction modes from grape pomace of sugars and tartaric acid compounds was carried out using mathematical planning (uniform rotatable plan) in a laboratory reactor. The influence of the extraction time, processing temperature, concentration of sodium chloride $(\mathrm{NaCl})$ in solution and active acidity $(\mathrm{pH})$ was studied on the process. Extracts with a given value of active acidity were prepared using a $\mathrm{NaOH}$ (sodium hydroxide) solution. The extraction rate is calculated by dividing the quantitative content of the substance in the extract by the total content in the system. 
In each experiment of the plan, after extraction, the content of solids and their extracted amount ( $\%$ of the total mass of pomace), as well as the quantitative content and degree of extraction of flavonoids from the feedstock, were determined in the solution. The results obtained indicated a significant effect on the extraction process of temperature, active acidity $(\mathrm{pH})$, extraction time and ionic strength of the solution $(\mathrm{NaCl}$ concentration) on the degree of extraction of flavonoids and dry substances from grape pomace.

Based on the results of the experiment, a neural network model of the multilayer perceptron was developed to create a data array using artificial intelligence, which served as the basis for optimizing the extraction modes. The optimization was carried out taking into account the fact that it is necessary to extract the minimum amount of flavonoids from the grape pomace and extract the maximum amount of other dry substances.

As a result of analyzing the data of the array, the optimal parameters of the factors for extracting chemical compounds from grape pomace $(7.9-8.2 \%$ of the total mass of pomace), soluble in polar solvents, were identified and checked in laboratory conditions (Table 2), the degree of extraction of flavonoids was insignificant and amounted to $0.5-2.3 \%$ of their total amount in the feedstock.

Table 2

Optimal parameters for the purification of grape pomace from sugars and tartaric acid compounds

\begin{tabular}{|c|c|c|c|}
\hline Time $(\tau), \min$. & Temperature (t) ${ }^{\circ} \mathrm{C}$ & Active acidity (pH) & $\begin{array}{l}\text { NaCI concentration in solution } \\
\qquad\left(C_{\mathrm{NaCl}}\right), \%\end{array}$ \\
\hline $20-25$ & $85-90$ & $7,2-7,4$ & $0,3-0,5$ \\
\hline
\end{tabular}

At the end of the extraction process, the precipitate was separated from the liquid fraction, crushed $(\sim$ up to 30 50 microns) and dried at $70-80^{\circ} \mathrm{C}$ to a water content of no more than $8 \%$. As a result, an odorless, dark cherry-colored, antioxidant powder supplement enriched in flavonoids was obtained.

The antioxidant activity of the food additive was determined by the change in the rate of lipid oxidation by monitoring the peroxide value, which characterizes the accumulation of lipid breakdown products, which is inversely proportional to the antioxidant activity.

The lipid model system was unsalted butter "Krestyanskoe" with a mass fraction of moisture $25 \%$ and fat $72.5 \%$. This choice is explained by the short shelf life of this product (up to 10 days at a temperature of no higher than 8 ${ }^{\circ} \mathrm{C}$ ), which makes it possible to visually simulate the process of inhibiting lipid oxidation with the help of antioxidants contained in the food supplement.

A food antioxidant additive was added to the unsalted Krestyanskoe butter in an amount of 3\% per $100 \mathrm{~g}$ of the model system (taking into account that the quantitative content of flavonoids in the system should be about $0.15 \%$ ) and placed in a thermostat at a temperature of $37 \mathrm{C}$, a control was prepared in parallel. a sample without additive, which was stored together with the experimental sample under the same conditions. The research results are presented in table. 3 and fig. 2.

Table 3

Accumulation of primary oxidation products in model lipid samples $\mathrm{q} \leq 0,05$

\begin{tabular}{|c|c|c|c|c|c|c|}
\hline \multirow{3}{*}{ 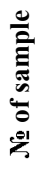 } & \multirow{3}{*}{ Sample } & \multicolumn{5}{|c|}{ Storage duration, days } \\
\hline & & 0 & 7 & 14 & 21 & 28 \\
\hline & & \multicolumn{5}{|c|}{ Peroxide number, mmol of active oxygen / $\mathrm{kg}$} \\
\hline 1 & "Krestyanskoe" unsalted butter (control) & 0,007 & 0,019 & 0,035 & 0,042 & 0,055 \\
\hline 2 & $\begin{array}{l}\text { Unsalted "Krestyanskoe" butter with food antioxidant additive } \\
\text { (experience) }\end{array}$ & 0,007 & 0,013 & 0,018 & 0,022 & 0,033 \\
\hline
\end{tabular}




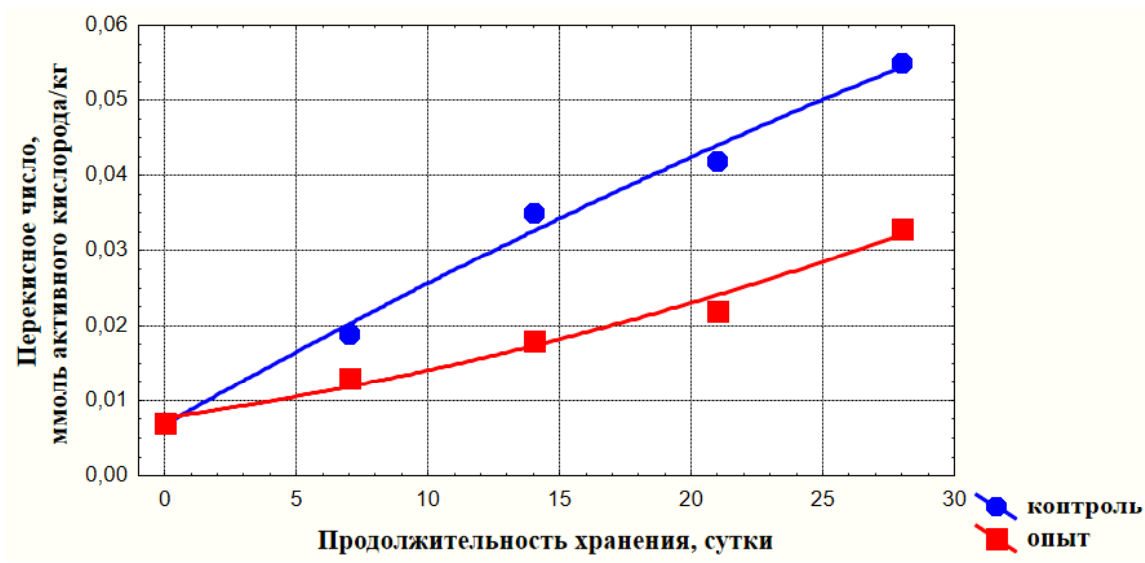

Fig. 2. Dynamics of the accumulation of primary oxidation products

The experimental results (Table 3, Fig. 2) show that the experimental sample after technological treatment had a peroxide number less than the control one $(0.033$ versus $0.055 \mathrm{mmol}$ of active oxygen $/ \mathrm{kg})$.

Thus, studies of the molecular characteristics of grape pomace flavonoids confirmed the antioxidant properties of these compounds, and the expediency of using polar solutions for the extraction of tartaric acids and sugars was established.

The optimal technological modes $(\mathrm{t}=85-90 \mathrm{oC},=20-25 \mathrm{~min} ., \mathrm{PH}=7.2-7.4, \mathrm{NaCl}$ concentration in the solution $-0.3-0.5 \%$ ) for extracting sugars and tartaric acids from the grape peel were revealed. compounds providing insignificant losses of flavonoids $(0.5-2.3 \%$ of the total amount in the feedstock).

The technology of an antioxidant food additive with preventive properties has been developed, which consists in extracting tartaric acids and sugars from grape pomace by extraction, separating the liquid fraction, crushing and drying the sludge.

Experiments on lipid model samples confirmed the antioxidant activity of the developed food additive.

\section{ЛИТЕРА ТУРА}

1. Абрамова, Ж. И. Человек и противоокислительные вещества. - Л.: Наука, 1985.-232 с.

2. Георгиевский, В. П. Биологически активные вещества .екарственных растений. Новосибирск: Наука, Сиб. отд-ние, 1990. - 333 c. ISBN 5-02-029240-0.

3. ГОСТ 25555.0-82.Продукты переработки плодов и овощей. Методы определения титруемой кислотности.

4. ГОСТ 8756.13-87. Продукты переработки плодов и овощей. Методы определения сахаров.

5. Моргунова А.В. Оптимизация питания студентов с использованием компьютерного моделирования. В сборнике: Современные исследования основных направлений гуманитарных и естественных наук. 2017. С. 175-179.

6. Моргунова А.В., Стюдеманн Т.А. Научно-технический прогресс в общественном питании Сборник III международных конференций профессорско-преподавательского состава и аспирантов СТИК (филиала) БУКЭП. 2017. С. $217-219$.

7. Хамицаева А.С., Газзаева М.С., Мамукаев 3.М.Использование четвертично аммониевых солей при производстве мясных изделий // Пищевая промышленность. 2007. №6. с. 60.

8. Хамицаева А.С., Мамукаев М.ІІ., Бритаев Б.Б. Изучение химического состава, биологической ценности, функционально-технологических характеристик ростков чечевицы // Известия Горского государственного аграрного университета. 2007. T. 44. № 2. C. 165.

\section{REFERENCES}

1. Abramova, Zh. I. Chelovek i protivookislitel'nye veshchestva. - L.: Nauka, 1985.- $232 \mathrm{~s}$.

2. Georgievskii, V. P. Biologicheski aktivnye veshchestva lekarstvennykh rastenii. Novosibirsk: Nauka, Sib. otd-nie, 1990. -333 s. ISBN 5-02-029240-0.

3. GOST 25555.0-82.Produkty pererabotki plodov i ovoshchei. Metody opredeleniya titruemoi kislotnosti.

4. GOST 8756.13-87. Produkty pererabotki plodov i ovoshchei. Metody opredeleniya sakharov.

5. Morgunova A.V. Optimizatsiya pitaniya studentov s ispol'zovaniem komp'yuternogo modelirovaniya. V sbornike: Sovremennye issledovaniya osnovnykh napravlenii gumanitarnykh i estestvennykh nauk. 2017. S. 175-179.

6. Morgunova A.V., Styudemann T.A. Nauchno-tekhnicheskii progress v obshchestvennom pitanii Sbornik III mezhdunarodnykh konferentsii professorsko-prepodavatel'skogo sostava i aspirantov STIK (filiala) BUKEHP. 2017. S. 217-219.

7. Khamitsaeva A.S., Gazzaeva M.S., Mamukaev Z.M.Ispol'zovanie chetvertichno ammonievykh solei pri proizvodstve myasnykh izdelii // Pishchevaya promyshlennost'. 2007. №6. s. 60.

8. Khamitsaeva A.S., Mamukaev M.N., Britaev B.B. Izuchenie khimicheskogo sostava, biologicheskoi tsennosti, funktsional'no-tekhnologicheskikh kharakteristik rostkov chechevitsy // Izvestiya Gorskogo gosudarstvennogo agrarnogo universiteta.

\section{OБ ABTOPAX | ABOUT AUTHORS}

Садовой Владимир Всеволодович, доктор технических наук, профессор кафедры технологии 
продуктов питания и товароведения, профессор кафедры товароведения и технологии обществешнго питания, Северо-Кавказский федеральный университет, Пятигорск; Ставропольский институт кооперации (филиал) Белгородский университет кооперации, экономики и права.

Sadovoy Vladimir Vsevolodovich, Doctor of Technical Sciences, Professor of the Department of Food Technology and Commodity Science, Professor of the Department of Commodity Science and Public Catering Technology, North Caucasus Federal University, Pyatigorsk; Stavropol Institute of Cooperation (branch) Belgorod University of Cooperation, Economics and Law.

Щедрина Татьяна Викторовна, кандидат технических наук, доцент кафедры технологии продуктов питания и товароведения, Северо-Кавказский федеральный университет, Пятигорск.

Shchedrina Tatiana Viktorovna, Candidate of Technical Sciences, Associate Professor of the Department of Food Technology and Commodity Science, North Caucasus Federal University, Pyatigorsk.

Мелентьева Вероника Валерьевна, магистрант кафедры товароведения и технологии общественного питания, Ставропольский институт кооперации (филиал) Белгородский университет кооперации, экономики и права.

Melentyeva Veronika Valerievna, Master's student of the Department of Commodity Science and Public Catering Technology, Stavropol Institute of Cooperation (branch) Belgorod University of Cooperation, Economics and Law.

Дрижд Наталья Алексеевна, кандидат технических наук, доцент кафедры товароведения и техноло-

общественного питания, Ставропольский институт кооперации (филиал) Белгородский университет кооперации, экономики и права.

Drizhd Natalia Alekseevna, Candidate of Technical Sciences, Associate Professor of the Department of Commodity Science and Public Catering Technology, Stavropol Institute of Cooperation (branch) Belgorod University of Cooperation, Economics and Law. 